\title{
Twenty-four hour changes in androgens, cortisol and prolactin concentrations in primitive Asiatic pigs
}

\section{Joanna Gromadzka-Ostrowska ${ }^{1}$, B. Barcikowski ${ }^{2}$ and Krystyna Jakubów-Durska ${ }^{3}$}

\author{
'Department of Dietetics, Warsaw Agricultural University \\ Nowoursynowska 166, 02-787 Warsaw, Poland \\ ${ }^{2}$ The Kielanowski Institute of Animal Physiology and Nutrition, \\ Polish Academy of Sciences \\ 05-110 Jablonna, Poland \\ ${ }^{3}$ Department of Genetics, Child and Mother Institute \\ Kasprzaka 17a, Warsaw, Poland
}

(Received 6 May 1999; accepted 7 October 1999)

\begin{abstract}
Twenty-four h changes in plasma concentrations of cortisol, prolactin and androgens in both sexes of primitive Asiatic pigs (Vietnamese - Sus scrofa vittatus) were investigated. Blood samples were drawn from indwelling femoral artery catheters and plasma concentrations of hormones were analysed by radioimmunoassay.

All three investigated hormones showed statistically significant $24 \mathrm{~h}$ changes in boars with higher levels in the morning (cortisol, prolactin, and androgens) and in the early (prolactin) or late (cortisol) evening. Patterns of plasma cortisol and prolactin concentrations in gilts were the same as in boars, whereas androgen concentrations in gilts were not changed. The boars' androgens showed $24 \mathrm{~h}$ changes but without a consistent circadian rhythm.

Only plasma cortisol concentrations in boars as well as in gilts had a circadian rhythm with the following cosine curve characteristics for boars and gilts, respectively: acrophases (point of $24 \mathrm{~h}$ with maximal hormone value) $9.24 \pm 5.23 \mathrm{~h}, 7.37 \pm 3.06 \mathrm{~h}$; amplitudes $1.70 \pm 1.07,2.25 \pm 1.67 \mathrm{ng} / \mathrm{ml}$ and $24 \mathrm{~h}$ means $9.20 \pm 0.72$ and $7.05 \pm 0.68 \mathrm{ng} / \mathrm{ml}$.
\end{abstract}

KEY WORDS: primitive pigs, circadian rhythm, androgens, cortisol, prolactin

1 Corresponding author 


\section{INTRODUCTION}

Primitive Asiatic (Vietnamese) pigs descended from the wild Asiatic hog (Sus scrofa vittatus) are native to South-East Asia. They have a fat body with very short legs and a smooth, dark grey hide. The head is strikingly massive and large in proportion to the pig's size. The face is extremely short, the muzzle is very broad and blunt, the erect ears are small. As previously demonstrated (Gromadzka-Ostrowska, 1980), they have very regular oestrous cycles and the hormonal events during the cycles are more regular than in other pig breeds. They have higher concentrations of hormones than in other pig breeds although the hormone profiles found during the oestrous cycle in Vietnamese pigs are broadly similar to those described for other breeds. Taking into consideration physiological specificity, it seems that Vietnamese pigs are very useful for hormonal study of reproductive processes and development in both boars and sows.

Circadian fluctuations in circulating glucocorticoid levels have been reported for many species, including pigs (Edqvist et al., 1980; Griffith and Minton, 1992; Janssens et al., 1995). In diurnal species such as the human and the pig, plasma glucorticoid levels are high in the early morning and then decline, reaching a nadir in the evening (Janssens et al., 1995). In noctumal animals an inverse pattern in the glucocorticoid level has been observed (Velasco et al., 1993). Circadian patterns of circulating cortisol are thought to result primarily from changes in plasma adrenocorticotrophin hormone in response to circadian changes in suprachiasmatic nucleus efferent pathways (Miller et al., 1996) and corticotrophin releasing hormone secretion (Nicholson et al., 1985). Circadian rhythms of prolactin and androgen concentrations in pigs are poorly understood and the reported results are conflicting.

The aim of the present study was to monitor twenty-four hour plasma cortisol, androgen, and prolactin concentrations in both sexes of primitive pigs to determine the diurnal patterns of these hormones.

\section{MATERIAL AND METHODS}

Asiatic, i.e. Vietnamese (Sus scrofa vittatus), primitive domestic pigs, 5 females and 4 males, 14-19 months old, were used in the experiment. The animals were housed in individual pens with a frec-access run out under natural lighting conditions. During the night they were kept under red lighting in separate cages. Some weeks before the start of the experiment the animals were accustomed to handling and the presence of humans during the night.

All animals were given a standard diet consisting of potatoes, wheat bran, ground barley, powdered skimmed milk, common salt, vitamins and minerals. They were allowed free access to water and diets. 
To allow repeated blood sampling without disturbing the pigs, all animals were surgically fitted by the technique described previously (Gromadzka et al., 1985) with a permanent Teflon catheter into a femoral artery such that the distal end was in the aorta. The catheter, $1 \mathrm{~m}$ long and $2.3 \mathrm{~mm}$ outer diameter, was fixed to the animal's back and filled with sterile heparinized physiological saline $(50$ i.u. $/ \mathrm{ml}$ $0.9 \%$ saline) and corked by a Teflon stopper after withdrawing the blood samples. This did not hamper the free outdoor movement of the pig.

Blood samples were taken from each animal eight times during one 24-h examination (at 07:00, 10:00, 13:00, 16:00, 19:00, 22:00, 01:00 and 04:00). Three examinations during four weeks were carried out in April and May when dark phases occurred between 19:00 and 04:00 h.

In gilts, swelling of the vulva and mating behaviour were used to confirm the timing of oestrus and blood was collected between days 7 and 11 of the oestrous cycles, when cortisol and testosterone were invariably at low levels (GromadzkaOstrowska, 1980). At this time prolactin concentrations were also below average (Gromadzka-Ostrowska et al., 1985).

Blood samples were collected directly from the catheter into a tube containing heparin. Samples were centrifuged and plasma was removed and stored at $-23^{\circ} \mathrm{C}$ until assay.

Plasma prolactin concentrations were determined by a highly specific doubleantibody radioimmunoassay technique (RIA) using a purified porcine prolactin (KK-2 purified by K. Kochman, Institute of Animals Physiology and Nutrition, Jabłonna, Poland) as the antigen. The details were described previously by Gromadzka-Ostrowska ct al. (1985). The antibody showed no cross-reaction with purified porcine $\mathrm{GH}, \mathrm{LH}$, or ACTH. The sensitivity of the assay was $0.20 \mathrm{ng} / \mathrm{ml}$ of plasma. The intra- and inter-assay coefficients of variation were 3 and $10 \%$, respectively.

Plasma testosterone concentrations were determined by a method described by Stupnicki (1985a). Assays were performed without extraction in $20 \mathrm{ml}$ aliquots of plasma using a rabbit antibody (aT/R7, obtained at from the Institute of Animal Physiology and Nutrition Jablonna, Poland) with high specific affinity for testosterone and dehydroepiandrostendione; thus the androgens assayed gave total plasma androgen activity. No cross-reactions with other androgen steroids were observed. The sensitivity of the androgen assay was $12.5 \mathrm{pg} / \mathrm{ml}$ and the intra- and interassay variation coefficients were 6 and $14 \%$, respectively.

Cortisol plasma concentrations were measured in unextracted $20 \mu \mathrm{l}$ aliquots of plasma by a RIA method according to Stupnicki (1985b) using a single specific rabbit antibody (a-F/R63 obtained from the Institute of Animal Physiology and Nutrition, Jabłonna, Poland) that showed cross-reaction with corticosterone (15\%) and desoxycorticosterone (3\%). Plasma transcortin was inactivated by heating samples at $75^{\circ} \mathrm{C}$ for $20 \mathrm{~min}$. The sensitivity of the cortisol assay was 
$0.02 \mathrm{ng} / \mathrm{ml}$, the intra- and inter-assay coefficients of variation were 7.7 and $11.6 \%$, respectively.

Mean values and their standard errors (SEM) were calculated for each of the 8 time points in the $24 \mathrm{~h}$ period of study. Statistically significant differences between particular diurnal points for all hormones in females and males were analysed using Student's t-test. The cosine curve characteristics for the 24 -h data were determined by a computer program developed from the equation described by Żużewicz et al.(1977).

\section{RESULTS}

The number of observations for each point of cortisol, prolactin and androgen concentrations was equal to the number of samples: 15 and 12 examinations for females and males, respectively.

The cortisol concentration in both females and males had two peaks, one in the morning at 10:00 which was significantly higher $(\mathrm{P}<0.05)$ than the other circadian points $(9.52 \pm 1.89 \mathrm{ng} / \mathrm{ml}$ for females and $13.93 \pm 1.77 \mathrm{ng} / \mathrm{ml}$ for males $)$ and one in the evening at $22: 00(9.23 \pm 2.17 \mathrm{ng} / \mathrm{ml}$ for females and $9.85 \pm 3.14 \mathrm{ng} / \mathrm{ml}$ for males $)$. A third cortisol peak occurred in boar plasma at 04:00 $(12.52 \pm 1.58 \mathrm{ng} / \mathrm{ml})$. Minimal $24 \mathrm{~h}$ cortisol concentrations were observed at 04:00 $(3.27 \pm 0.55 \mathrm{ng} / \mathrm{ml})$ in gilts and at 16:00 $(5.79 \pm 0.43 \mathrm{ng} / \mathrm{ml})$ and at 01:00 $(6.23 \pm 1.77 \mathrm{ng} / \mathrm{ml})$ in boars (Figure 1). The mean $24 \mathrm{~h}$ cortisol concentration was $7.05 \pm 0.68 \mathrm{ng} / \mathrm{ml}$ with high individual variability ( $76 \%$ coefficient of variation) in gilts. In boars the mean twenty-four $h$ cortisol concentration was $9.2 \pm 0.72 \mathrm{ng} / \mathrm{ml}$ with a little lower individual variability $(62 \%$ coefficient of variation). The results presented suggest the existence of circadian rhythms in plasma cortisol concentrations in Vietnamese gilts and boars. Characteristic features of the rhythms were revealed by cosine curve analysis and are shown in Table 1.

Circadian rhythms for plasma prolactin concentrations in both sexes of Vietnamese pigs were non-significant by the cosine curve analysis, although there were well-marked twenty-four h changes with two higher levels, one at 10:00

TABLE 1

Cosine curve characteristics of circadian rhythm in cortisol concentrations in primitive Asiatic boars and gilts

\begin{tabular}{lccc}
\hline & Acrophase & Amplitude & $24 \mathrm{~h}$ mean \\
\hline Boars & $9.24 \pm 5.23 \mathrm{hr}$ & $1.70 \pm 1.07 \mathrm{ng} / \mathrm{ml}$ & $7.05 \pm 0.68 \mathrm{ng} / \mathrm{ml}$ \\
Gilts & $7.37 \pm 3.06 \mathrm{hr}$ & $2.25 \pm 1.67 \mathrm{ng} / \mathrm{ml}$ & $9.20 \pm 0.72 \mathrm{ng} / \mathrm{ml}$ \\
\hline
\end{tabular}

${ }^{1}$ point of $24 \mathrm{~h}$ with maximal hormone value 

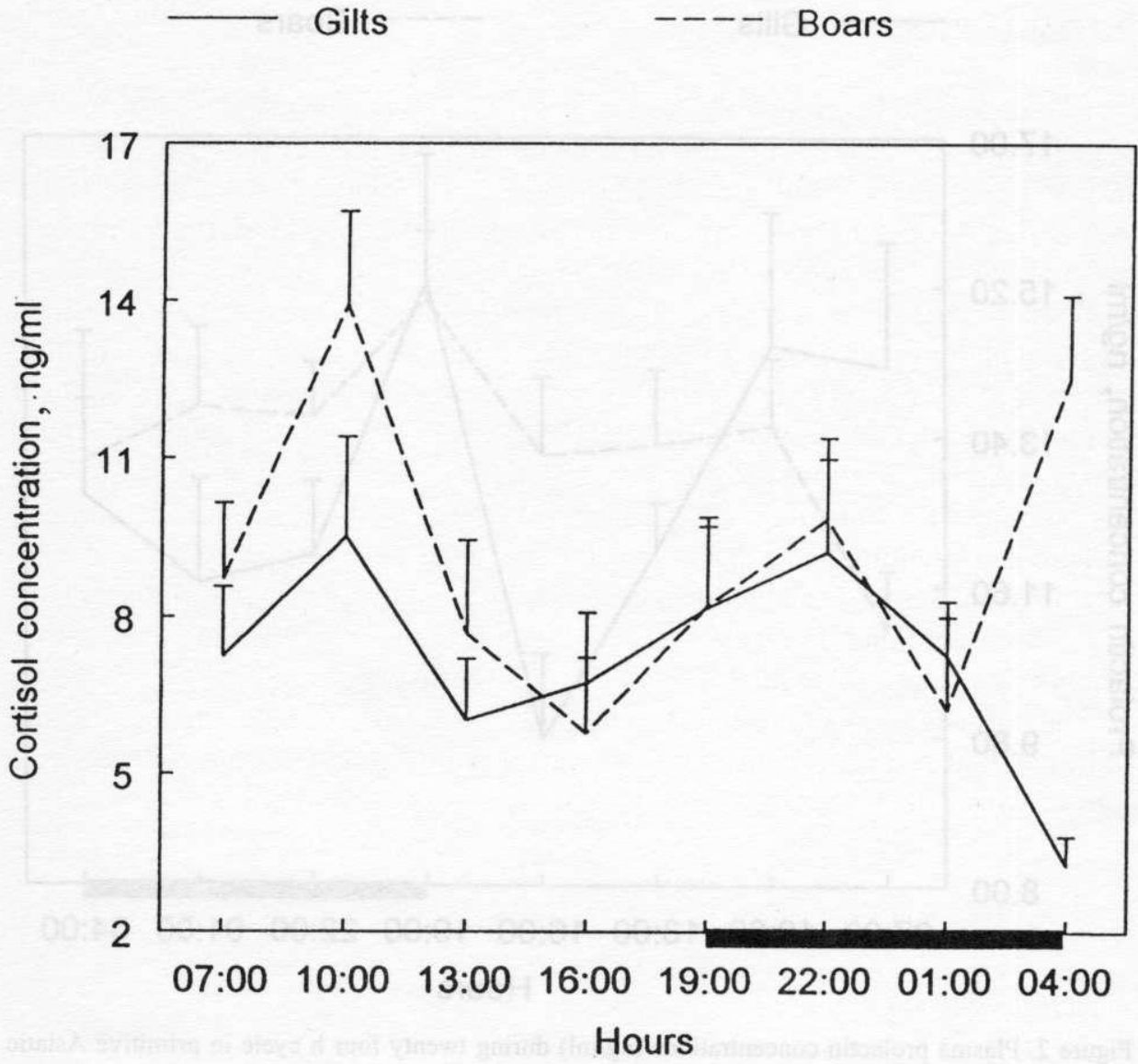

Figure 1. Plasma cortisol concentrations $(\mathrm{ng} / \mathrm{ml})$ during twenty four h cycle in primitive Asiatic gilts and boars. Dark period is indicated by the horizontal black bar

$(14.5 \pm 1.6 \mathrm{ng} / \mathrm{ml}$ in females and $13.54 \pm 1.07 \mathrm{ng} / \mathrm{ml}$ in males) and the other at 19:00 $(15.28 \pm 2.52 \mathrm{ng} / \mathrm{ml}$ in females and $15.05 \pm 1.39 \mathrm{ng} / \mathrm{ml}$ in males). Minimal prolactin concentrations at 16:00 $(9.77 \pm 1.03 \mathrm{ng} / \mathrm{ml})$ in gilts and at 07:00 $(11.09 \pm 0.7 \mathrm{ng} / \mathrm{ml})$ in boars were also observed (Figure 2). Mean plasma twenty-four h prolactin concentrations were $12.7 \pm 0.65 \mathrm{ng} / \mathrm{ml}$ and $13.26 \pm 0.43 \mathrm{ng} / \mathrm{ml}$ in females and males, respectively. Coefficients of variation in prolactin plasma levels were $45 \%$ in gilts and $35 \%$ in boars.

Androgen concentrations in females did not change significantly during the $24 \mathrm{~h}$ period, the overall mean being $481.7 \pm 19.6 \mathrm{pg} / \mathrm{ml}$ of plasma. In boars the highest androgen concentration occurred at 10:00 $(2.88 \pm 0.92 \mathrm{ng} / \mathrm{ml})$ and the lowest at $16: 00 \mathrm{~h}(0.54 \pm 0.10 \mathrm{ng} / \mathrm{ml})$ (Figure 3$)$. Coefficients of variation in androgen plas- 


\section{- Gilts}
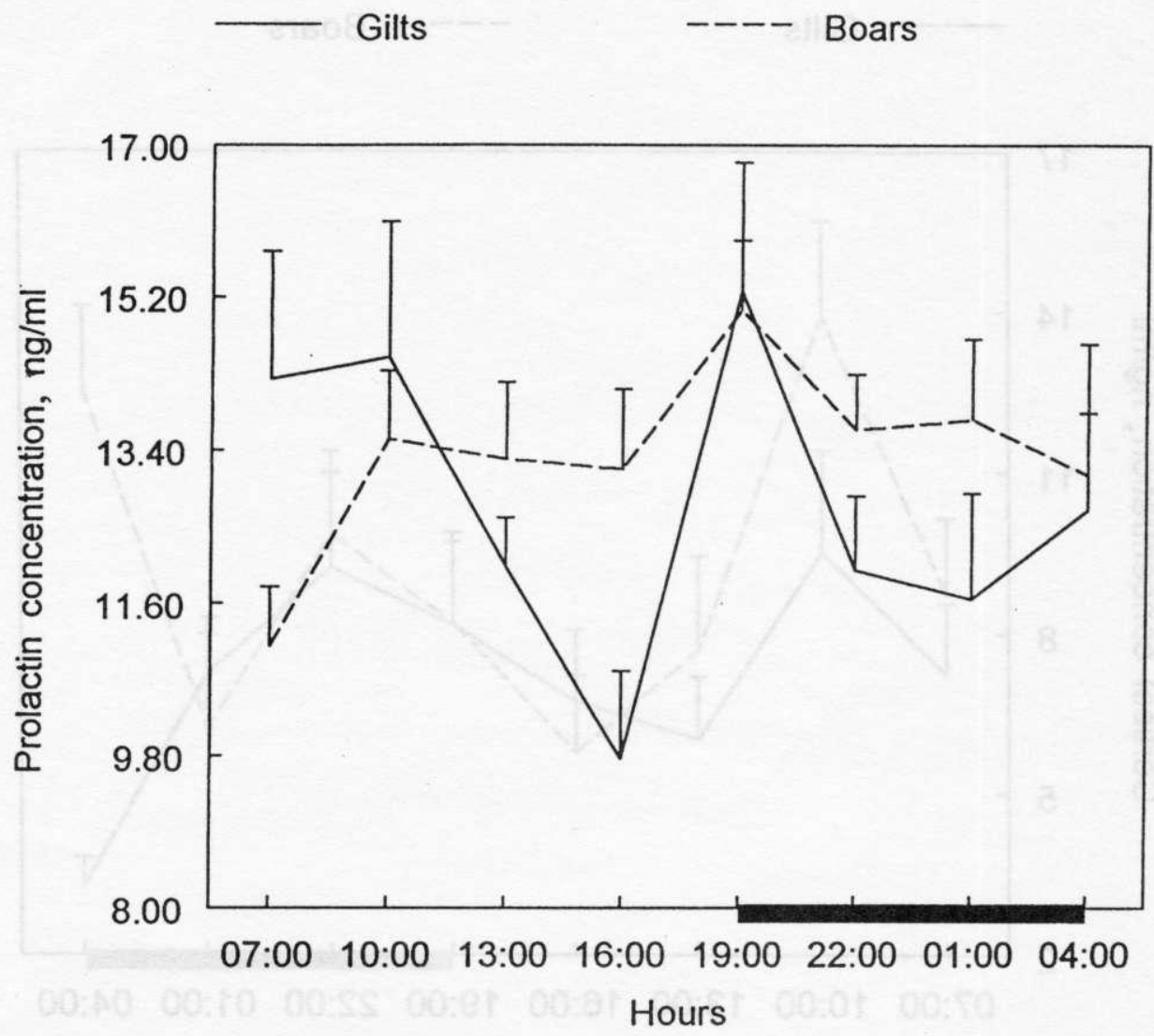

Figure 2. Plasma prolactin concentrations $(\mathrm{ng} / \mathrm{ml})$ during twenty four h cycle in primitive Asiatic gilts and boars. Explanation as for Figure 1

ma concentrations were $39 \%$ in gilts and $56 \%$ in boars, mean $24 \mathrm{~h}$ concentrations were $1.42 \pm 0.25 \mathrm{ng} / \mathrm{ml}$ and $481.7 \pm 19.6 \mathrm{pg} / \mathrm{ml}$ in males and females, respectively. The cosine curve analysis of the $24 \mathrm{~h}$ data revealed that there was no significant circadian rhythm in androgens.

\section{DISCUSSION}

When blood samples are collected for plasma hormone determinations, especially of cortisol and prolactin, it has been considered that stress may influence hormonal secretion. In the present experiment we tried to avoid stress as much as possible by using long indwelling catheters for blood collection that allowed free 

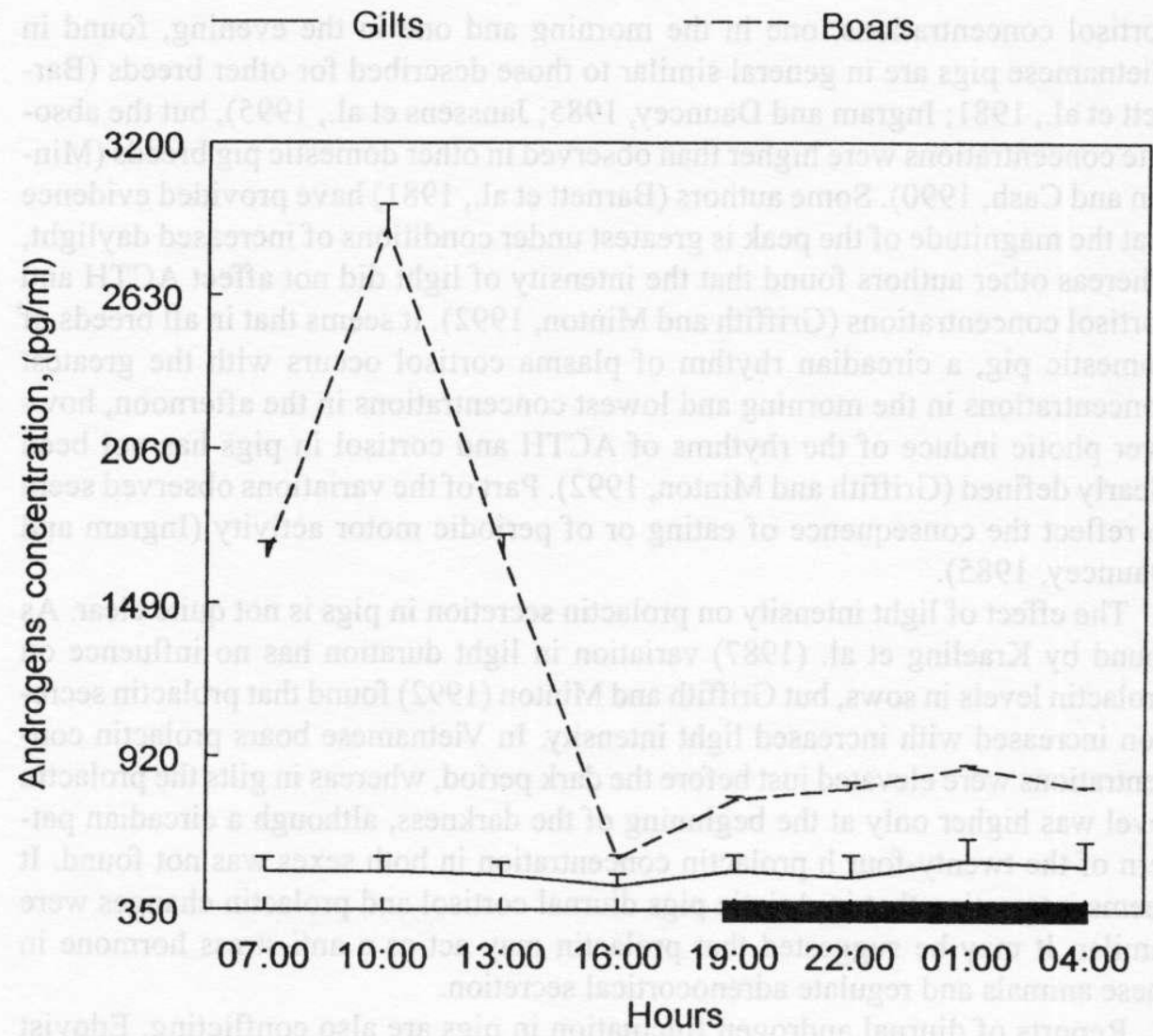

Figure 3. Plasma androgens concentations $(\mathrm{pg} / \mathrm{ml})$ during twenty four $\mathrm{h}$ cycle in primitive Asiatic gilts and boars. Explanation as for Figure 1

outdoor movement of the pig and blood sampling without disturbing the animals. The employment of a red light during night and accustoming the pigs to the presence of a person during the night allowed samples to be collected without disturbing the animals.

As described previously (Gromadzka-Ostrowska, 1980), primitive pigs have higher concentrations of LH, estradiol, androgens, cortisol, and progesterone, although the secretion patterns are similar to those found in other pig breeds (Parvizi et al., 1976; Estienne et al., 1998; Mariscal et al., 1998). Similar observations have been made by Ravault et al. (1982), confirming that in wild sows prolactin concentrations are higher than in domestic breeds.

The results presented confirm the existence of a circadian rhythm in plasma cortisol concentrations in Vietnamese gilts as well as in boars. The two peaks of 
cortisol concentrations, one in the morning and one in the evening, found in Vietnamese pigs are in general similar to those described for other breeds (Barnett et al., 1981; Ingram and Dauncey, 1985; Janssens et al., 1995), but the absolute concentrations were higher than observed in other domestic pig breeds (Minton and Cash, 1990). Some authors (Barnett et al., 1981) have provided evidence that the magnitude of the peak is greatest under conditions of increased daylight, whereas other authors found that the intensity of light did not affect ACTH and cortisol concentrations (Griffith and Minton, 1992). It seems that in all breeds of domestic pig, a circadian rhythm of plasma cortisol occurs with the greatest concentrations in the morning and lowest concentrations in the afternoon, however photic induce of the rhythms of $\mathrm{ACTH}$ and cortisol in pigs has not been clearly defined (Griffith and Minton, 1992). Part of the variations observed seem to reflect the consequence of eating or of periodic motor activity (Ingram and Dauncey, 1985).

The effect of light intensity on prolactin secretion in pigs is not quite clear. As found by Kraeling et al. (1987) variation in light duration has no influence on prolactin levels in sows, but Griffith and Minton (1992) found that prolactin secretion increased with increased light intensity. In Vietnamese boars prolactin concentrations were elevated just before the dark period, whereas in gilts the prolactin level was higher only at the beginning of the darkness, although a circadian pattern of the twenty-four h prolactin concentration in both sexes was not found. It seems interesting that in Asiatic pigs diurnal cortisol and prolactin changes were similar. It may be suggested that prolactin may act as a anti-stress hormone in these animals and regulate adrenocortical secretion.

Reports of diurnal androgen fluctuation in pigs are also conflicting. Edqvist et al. (1980) and Dusza (personal communication) were unable to detect any rhythms in androgen concentrations whereas in Asiatic boars, morning increases in total plasma androgens were observed. In miniature boars, Ellendorf et al. (1975) also found lower testosterone concentrations during the evening and night compared with morning. Claus and Gimenez (1977) stated that maximum androgen (testosterone and $5 \alpha$-androst-16-en-3-one) concentrations occur twice daily, in the afternoon and after midnight. Some authors observed remarkable variations in testosterone concentrations in boar peripheral plasma during the day, although clear diurnal rhythms occurred in only a few cases. Liptrap et al. (1986) found an increase in testosterone values once in a $12 \mathrm{~h}$ period for only $70 \%$ of the investigated animals and a significant correlation between $\mathrm{LH}$ and testosterone in only $40 \%$ of them. Navratil et al. (1978) also did not observe a regular periodicity of testosterone concentrations in boars and statistically significant differences of hormonal levels between individual boars. In all Vietnamese boars studied during the particular three $24 \mathrm{~h}$ cycles, morning increases in androgens were observed. 


\section{CONCLUSIONS}

Primitive Vietnamese pigs have a very regular diurnal pattern of hormonal changes and higher hormone concentrations compared to those found in other pig breeds. In both sexes cortisol and prolactin concentrations showed well-marked twentyfour h changes, although a circadian rhythm character was only observed for cortisol concentration.

\section{ACKNOWLEDGEMENTS}

We thank Dr. K. Kochman, The Kielanowski Institute of Animal Physiology and Nutrition in Jabłonna, for the gift of purified porcine prolactin standard, Mrs. E. Szylarska-Góźdź and Mrs. B. Zalewska for their valuable assistance in animal care and blood sampling and Dr See'd Halilu Bawa from the Department of Dietetics of the Warsaw Agricultural University for critical evaluation of the manuscript.

\section{REFERENCES}

Barnett J.G., Winfield C.G., Cronin G.M., Makin A.W., 1981. Effects of photoperiod and feeding on plasma corticosteroid concentrations and maximum corticosteroid-binding capacity in pigs. Aust. J. Biol. Sci. 34, 577-563

Claus R., Gimenez T., 1977. Diurnal thythm of 5 $\alpha$-androst-16-en-3-one and testosterone in peripheral plasma of boars. Acta Endocrinol. 84, 200-206

Edqvist L.E., Einarsson S., Larsson K., Lundström K., 1980. Diurnal variations in peripheral plasma levels of testosterone, androsterone and cortisol in boars. Acta Vet. Scand. 21, 451-453

Ellendorf F., Parvizi N., Pomerantz D.K., Hartjen R., Köning A., Smidt S., Elseasser F., 1975. Plasma $\mathrm{LH}$ and testosterone in adult malc pigs: $24 \mathrm{hr}$ fluctuations and effect of copulation. J. Endocrinol. $67,403-410$

Estienne M.J., Hurlock W.F., Barb C.R., 1998. Serum concentrations of luteinizing hormone, growth hormone and cortisol in gilts treated with $\mathrm{N}$-methyl-D,L-aspartate during the estrous cycle or after ovariectomy. J. Anim. Sci. 76, 2162-2168

Griffith M.K., Minton J.E., 1992. Effect of light intensity on circadian profiles of melatonin, prolactin, ACTH and cortisol in pigs. J. Anim. Sci. 70, 492-498

Gromadzka-Ostrowska J., 1980. Hormonal secretion patterns during oestrus cycle of different types of primitive pigs (in Polish). Ph. D. Thesis, Warsaw University, Poland

Gromadzka-Ostrowska J., Madej A., Barcikowski B., 1985. Peripheral plasma prolactin concentrations during oestrus cycle in different types of primitive pigs. J. Reprod. Fertil. 73, 159-164

Ingram D.L., Dauncey M.J., 1985. Circadian rhythms in the pig (minireview). Comp. Biochem. Physiol. 82A, 1-5 
Janssens C.J.J.G., Helmond F.A., Wiegant V.M., 1995. The effect of chronic stress on plasma cortisol concentrations in cyclic female pigs depends on the time of day. Domest. Anim. Endocrinol. $12,167-177$

Krealing R.R., Rampacek G.B., Mabry J.W., Cunningham F.L., Pinkert C., 1983. Serum concentrations of pituitary and adrenal hormones in female pigs exposed to two photoperiods. J. Anim. Sci. $57,1243-1250$

Liptrap R.M., Doble E., Cheng K.W., 1986. Plasma concentration profiles of gonadotrophins and testosterone in the adult boar. Can. J. Vet. Res. 50, 427-432

Marisca! D.V., Bergfeld E.G., Cupp A.S., Kojima F.N., Fike K.E., Sanchez T., Werhman M.E., Johnson R.K., Kittok R.J., Ford J.J., Kinder J.E., 1998. Concentrations of gonadotrophins, estradiol and progesterone in sows selected on an index of ovulation rate and embryo survival. Anim. Reprod. Sci. 54, 31-43

Miller J.D., Morin L.P., Schwartz W.J., Moore R.Y., 1996. New insights into the mammalian circadian clock. Sleep 19,641-667

Minton J.E., Cash W.C., 1990. Effect of cranial sympathectomy on circadian rhythms of cortisol, adrenocorticotropic hormone and melatonin in boars. J. Anim. Sci. 68, 4277-4284

Navratil S., Hruska K., Franek M., 1978. Variation of the scrum testosterone level in boars during 24 $\mathrm{h}$ and during a period of several days. Vet. Med.-Czech 23, 87-95

Nicholson S., Lin J., Mahmoud S., Cambell E., Gillham B., Jones M., 1985. Diurnal variations in responsiveness of the hypothalamo-pituitary-adrenocortical axis of rat. Neuroendocrinology 40, 217-224

Parvizi N., Elsaesser F., Smidı G., Ellendorff E., 1976. Plasma lutcinizing hormone and progesterone in the adult female pig during the oestrous cycle, late pregnancy and lactation and after ovariectomy and pentobarbitone treatment. J. Endocrinol. 69, 193-203

Ravault J.P., Martinat-Botte F., Mauget R., Martinat N., Locatelli A., Bariteau F., 1982. Influence of the duration of daylight on prolactin secretion in the pig: hourly rhythm in ovariectomized females, monthly variation in domestic (male and femalc) and wild strains during the year. Biol. Reprod. 27, 1084-1089

Stupnicki R., 1985a. Testosteron. In: F. Kokot, R. Stupnicki (Editors). Radiommunoassay and Radiocompetition Methods Applied in Clinics (in Polish). PZWL, Warszawa, pp. 273-281

Stupnicki R., 1985b. Glicocorticosteroids. In: F. Kokot, R. Stupnicki (Editors). Radiommunoassay and Radiocompetition Methods Applied in Clinics (in Polish). PZWL, Warszawa, pp. 235-244

Velasco A., Huerta I., Granda T.G., Cachcro T.G., Menedez E., Martin B., 1993. Circadian rhythms of plasma corticosterone at different times after induction of diabetes. Responses to corticoadrenal stimulation in light and dark phases. Life Sci. 52, 956-974

Żużewicz K., Reyment-Kisiel E., Kwarecki K., 1977. Basic mathematico-statistical analysis of cicardian rhythms (in Polish). Med. Lot. 54, 17-24 


\section{STRESZCZENIE}

Dwudziestoczterogodzinne zmiany stężenia androgenów, kortyzolu i prolaktyny u prymitywnych świń azjatyckich

Badano okołodobowe zmiany stężenia androgenów, kortyzolu i prolaktyny w osoczu krwi prymitywnych świń azjatyckich (Sus vittatus) obu płci. Hormony oznaczano metodą RIA.

U knurów wszystkie trzy badane hormony wykazywały 24-ro godzinną zmienność stężenia z najwyższym poziomem rano (androgeny, kortyzol i prolaktyna) i wczesnym (prolaktyna) lub późnym (kortyzol) wieczorem. Analogiczne zmiany stężenia kortyzolu i prolaktyny obserwowano u loch, natomiast poziom androgenów u nich nie zmieniał się w ciągu doby.

Jak wynika z analizy koła kosinorów jedynie zmiany stężenia kortyzolu u obu płci mają charakter zmian okołodobowych (akrofaza $9.24 \pm 5.23$ i $7.37 \pm 3.06$ g; amplituda $1.7 \pm 1.07$ i $2.25 \pm 1.67 \mathrm{ng} / \mathrm{ml}$; stężenie średnie $9,20 \pm 0.72$ i $7.05 \pm 0.68 \mathrm{ng} / \mathrm{ml}$ odpowiednio dla knurów i loch). 